\title{
Alain Goulet, André Gide: écrire pour vivre
}

\section{Emanuele Kanceff}

\section{(2) OpenEdition}

\section{Journals}

\section{Edizione digitale}

URL: https://journals.openedition.org/studifrancesi/39766

DOI: 10.4000/studifrancesi.39766

ISSN: 2421-5856

\section{Editore}

Rosenberg \& Sellier

\section{Edizione cartacea}

Data di pubblicazione: 1 décembre 2004

Paginazione: 408-409

ISSN: 0039-2944

\section{Notizia bibliografica digitale}

Emanuele Kanceff, «Alain Goulet, André Gide: écrire pour vivre», Studi Francesi [Online], 143 (XLVIII | II) | 2004, online dal 30 novembre 2015, consultato il 19 mai 2021. URL: http://journals.openedition.org/ studifrancesi/39766 ; DOI: https://doi.org/10.4000/studifrancesi.39766

Questo documento è stato generato automaticamente il 19 mai 2021.

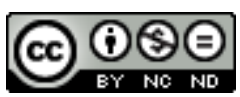

Studi Francesi è distribuita con Licenza Creative Commons Attribuzione - Non commerciale - Non opere derivate 4.0 Internazionale. 


\title{
Alain Goulet, André Gide: écrire pour vivre
}

\author{
Emanuele Kanceff
}

NOTIZIA

ALAIN GOULET, André Gide: écrire pour vivre, Paris, José Corti, 2002 (“Les essais”), pp. 351.

In questo interessante volume il noto specialista gidiano ha raccolto una lunga serie di suoi scritti già pubblicati in riviste o volumi negli ultimi trent'anni (dal 1972 al 2001, se non ci sbagliamo) e che riordinati così secondo un rigoroso filo logico e tematico formano un insieme molto piacevole a leggersi. L'A. li ha fatti precedere da una bella prefazione, che non è indicata come tale ma porta il n. 1 della serie di capitoli e prende il titolo da una frase dello scrittore, quasi un testamento spirituale, che si legge nel suo ultimo Thésée: «J'ai fait mon œuvre, j’ai vécu». 